\title{
Dysphagia rehabilitation in post-COVID patients: Review of the literature
}

\author{
Jimena Cano-Crespo ${ }^{1}$, Héctor De la Torre-Barrios ${ }^{1}$, Carolina D. Tejeda-Franco ${ }^{1}$, Itzel Solís-Sánchez¹, \\ Nallely Bueno-Hernández ${ }^{2}$, and Annel Gómez-Coello ${ }^{1 *}$ \\ ${ }^{1}$ Phoniatrics Division, "Luis Guillermo Ibarra Ibarra"National Rehabilitation Institute, Mexico City; ${ }^{2}$ Research Department, Hospital General de México, \\ Mexico City. Mexico
}

\begin{abstract}
COVID-19 causes acute respiratory failure syndrome (SIRA), leading patients to require intubation in the intensive care unit (ICU). A common complication of this ventilatory support is dysphagia, which has a prevalence of up to $30 \%$. This work aims to describe rehabilitation methods in patients with coronavirus infection based on levels of evidence according to the GRADE System, so a systematic review of the literature was carried out. The selected articles were divided into the following subtopics: diagnosis of dysphagia and rehabilitation in COVID patients. The gold standard for the diagnosis of dysphagia is the videofluoroscopic swallowing study (VFS). Fiberoptic Evaluation of Swallowing Assessment (FEES) has high sensitivity and specificity, although they have the disjunction of an aerosol-generating procedure (AGP); however, in a pandemic situation, the study of choice in the literature is VF. Once the diagnosis is made, it is necessary to initiate rehabilitation as soon as possible, even from hospitalization in patients who have hemodynamic stability to prevent long-term effects and promote normal swallowing even before discharge. In patients with COVID-19 infection dysphagia, the risk-benefit of assessment tools and therapy used for diagnosis should be decided to help to maintain social distancing. It becomes imperative to carry out clinical studies with high levels of evidence that allow us to generate Clinical Practice Guides for the benefit of our patients.
\end{abstract}

Keywords: Dysphagia. COVID-19. Swallowing rehabilitation.

\section{Introduction}

Coronavirus 19 disease (COVID-19) spread from Wuhan, China in December 2019 and declared a pandemic by the World Health Organization (WHO) on March 11,2020 , produces severe acute respiratory syndrome as one of its complications associated with coronavirus 2 (SARS-CoV-2) 1 .

Dyspnea occurs in $55 \%$ of patients and is characterized by Progressive Respiratory Distress Syndrome (ARDS) and even death. Most patients admitted to hospital report symptoms such as dyspnea and cough, and many of them end up on respiratory support in the intensive care unit (ICU) ${ }^{1}$.

Among patients intubated in the ICU, a frequent complication after extubation is dysphagia, with a prevalence of up to $30 \%$ according to data reported by Dawson $\mathrm{C}^{2}$. It can be characterized by difficulty in initiating swallowing, nasal regurgitation, aspiration in the airway and/or presence of pharyngeal residue, secondary to incoordination between swallowing and breathing,

\section{Correspondence:}

*Annel Gómez-Coello

E-mail: annelgomezc@gmail.com,

Date of reception: 12-07-2021

Date of acceptance: 21-09-2021

angomez@inr.gob.mx
Available online: 07-03-2022

Rev Med Hosp Gen Mex. 2022;85(1):44-49 www.hospitalgeneral.mx 0185-1063/@ 2021 Sociedad Médica del Hospital General de Mexico. Published by Permanyer. This is an open access article under the CC BYNC-ND license (http://creativecommons.org/licenses/by-nc-nd/4.0/) 
these two-share neurological, physiological, structural and functional systems ${ }^{1,2}$.

Endotracheal intubation can result in laryngeal trauma, causing vocal cord and arytenoid edema, granulo$\mathrm{ma}$, and vocal cord paralysis. The presence of an endotracheal tube for more than 4 days is related to dysphagia in $86 \%$ of cases. In patients who require endotracheal intubation, the appearance of dysphagia is secondary to multifactorial changes, mainly mechanical and cognitive ${ }^{1}$.

\section{Objective}

Describe the methods of swallowing rehabilitation in patients with a history of SARS-CoV-2 infection.

\section{Material and Methods}

A systematic review of the literature was carried out to determine the rehabilitation of dysphagia in patients with a history of COVID infection, in which an applied search strategy was carried out. The inclusion criteria are:

Type of design: qualitative and quantitative methodologies were included for the review, including experimental, quasi-experimental and descriptive designs, as well as expert consensus and review articles.

Type of measures:

Language of the documents: studies in Spanish and English were included.

Temporality: March 2020 to February 2021.

The exclusion criteria were articles where clinical case and letters to the editor.

\section{Bibliographic search}

The Pubmed, MedLine, Scopus, Science Direct and Scielo databases were consulted using an applied search strategy that includes DeCS and MeSH descriptors, using the terms: dysphagia, swallowing, deglution, rehabilitation. With the terms equations were constructed using the AND and OR connectors. These articles should answer the question: What is the best rehabilitation method for dysphagia in post-COVID patients? Articles were staged according to their level of evidence, according to the Center of Evidence-Based Medicine (CEBM).

\section{Article selection process}

The checklist of the Preferred Reporting Items for Systematic Reviews and Meta Analyzes (PRISMA) method were used. The articles obtained with the previously described search strategy were subjected to a selection process based on the title and abstract, then the rest of the content of the article was read and analyzed. Finally, the search results were imported into the Mendeley reference manager for your organization. The records were exported to an Excel document to subsequently carry out the selection of studies relevant to the investigation.

\section{Results}

Thirty-four documents were found with the established terms, of which 13 fit the inclusion criteria (Table 1), they were ordered by chronological reference, including the main author, study design and results. The level of evidence was classified according to the GRADE System (Grading of Recommendations, Assessment, Development and Evaluation) ${ }^{3}$.

\section{Discussion}

From the selected articles, they were divided into the following subtopics: diagnosis of dysphagia and rehabilitation in COVID patients. It is important to emphasize that according to the GRADE system, the levels found in the selected articles correspond to levels with low evidence, which could be due to the recent appearance of COVID-19, and the difficulty in being able to systematize swallowing studies in the context of the pandemic.

The recommended management in Acute Respiratory Failure Syndrome (SIRA) due to COVID-19 is early intubation that can have dysphagia as sequelae in $3-62 \%$ of patients when it is maintained for more than 4 days. According to Mohan R, these sequelae can last for up to 6 months. Patients with COVID are pronated for 12-18 hours to maintain saturation levels, which can increase the risk of aspiration of saliva and secretions, in addition to preventing proper oral hygiene, which can cause aspiration of microorganisms ${ }^{1-6}$.

In these patients there may also be olfactory, taste and pharyngolaryngeal sensitivity alterations which have an impact on the dysphagia of these patients; this is important for the evaluation, diagnosis and rehabilitation, according to that reported by Vergara $\mathrm{J}^{6-9}$.

According to Stierli $\mathrm{S}$ et al., the tracheostomy also favors the desensitization of the structures, losing the gag reflex and vocal clearance, in addition to increasing the risk of aspiration pneumonia. To facilitate verbal communication and food intake in intensive care patients, 
Table 1. Level of evidence according to the Centre of Evidence-Based Medicine

\begin{tabular}{|c|c|c|c|}
\hline Author & Year & Findings or conclusions & $\begin{array}{l}\text { Level of } \\
\text { evidence } \\
\text { CEBM* }\end{array}$ \\
\hline Mohan R & 2020 & $\begin{array}{l}\text { Dysphagia is associated with malnutrition, dehydration, aspiration pneumonia, } \\
\text { and death. Post-extubation rehabilitation is recommended to minimize } \\
\text { long-term effects. }\end{array}$ & 5 \\
\hline Dawson C & 2020 & $\begin{array}{l}\text { The average start of oral post-extubation in post-covid- } 19 \text { patients with } \\
\text { dysphagia was } 5.3 \text { days and in patients with tracheostomy } 14.8 \text { days. The } \\
\text { more days the intubation lasted the more days to start the oral route. The } \\
\text { average days of therapy were } 8.6 \text {. Postcovid dysphagia prevalence was } 30 \% \text {. } \\
\text { Most of the patients required modifications to the diet due to problems in the } \\
\text { oral phase, thickening liquids, tongue and lip exercises. Nebulizations with } \\
\text { saline solution were used to avoid the thickness of the secretions. The } \\
\text { emotional state and delirium affected many patients for their recovery. }\end{array}$ & $2 a$ \\
\hline Fritz MA & 2020 & $\begin{array}{l}\text { Videofluoroscopy is the method of choice for the evaluation of swallowing in } \\
\text { SARS-COV2 positive patients or with a high probability of infection. Intubation } \\
\text { longer than } 4 \text { days is associated with swallowing problems. }\end{array}$ & 5 \\
\hline Kimura Y & 2020 & $\begin{array}{l}\text { The risk of COVID-19 infection in swallowing therapy can be decreased by } \\
\text { direct contact with the patient and with the appropriate personal protective } \\
\text { equipment. Proper oral hygiene is recommended. Tracheostomy along with } \\
\text { surgical aspiration of secretions helps reduce complications of post-COVID-19 } \\
\text { dysphagia. }\end{array}$ & 5 \\
\hline Stierli S & 2020 & $\begin{array}{l}\text { After } 2 \text { weeks of swallowing therapy, patients with tracheostomy began to eat } \\
\text { a soft diet with the need for tracheal aspiration. Early intervention and speech } \\
\text { and swallowing therapy and the use of ventilator compatible speech valves } \\
\text { decrease the negative consequences of prolonged intubation. }\end{array}$ & 4 \\
\hline Vergara $\mathrm{J}$ & 2020 & $\begin{array}{l}\text { Swallowing therapy in post-COVID-19 patients with tracheostomy is aimed at } \\
\text { manipulation of the balloon, safe swallowing measures, tracheal suction, } \\
\text { communication (the use of valves for speech, digital occlusion) and } \\
\text { decannulation (inflation of the balloon); and in laryngectomized patients, } \\
\text { respiration (use filters or masks on the stoma), pulmonary aspiration, and } \\
\text { laryngeal speech are recommended. }\end{array}$ & $3 a$ \\
\hline Coutts KA & 2020 & $\begin{array}{l}\text { Dysphagia is a frequent complication in post COVID patients. Speech and } \\
\text { language therapists are therefore an essential part of the treatment of these } \\
\text { patients but it is important to take measures to avoid close contact with } \\
\text { patients where distance can be maintained and the generation of aerosols } \\
\text { can be reduced. }\end{array}$ & 5 \\
\hline $\begin{array}{l}\text { Castillo- Allendes } \\
\text { A }\end{array}$ & 2020 & $\begin{array}{l}\text { Recommendations are issued to minimize the risk of contagion and reduce } \\
\text { contact with patients in voice therapy. }\end{array}$ & 5 \\
\hline Francesco A & 2021 & $\begin{array}{l}\text { In stable patients hospitalized with severe COVID-19 it is recommended to } \\
\text { start swallowing and pulmonary therapy. }\end{array}$ & 3a \\
\hline Mooney B & 2020 & $\begin{array}{l}\text { In post-covid-19, post-extubated, and tracheostomy patients, therapy was } \\
\text { emphasized in a sitting posture, strengthening the muscles for swallowing, } \\
\text { improving lung capacity, and participating in different activities. Digital } \\
\text { occlusion of the tracheostomy helped verbal communication, motivation and } \\
\text { participation as well as the contact of patients with their families through } \\
\text { applications. }\end{array}$ & 4 \\
\hline Pandian V & 2021 & $\begin{array}{l}\text { Otolaryngologists must participate as part of the multidisciplinary team in the } \\
\text { treatment of post-COVID patients in sequelae such as dysphagia, dysphonia, } \\
\text { anosmia, dysgeusia, hearing loss, vertigo, among others. }\end{array}$ & 5 \\
\hline Meister KD & 2020 & $\begin{array}{l}\text { It is recommended to take precautions in aerosol generating procedures, to } \\
\text { minimize the exposure of health workers, caregivers and patients. It is } \\
\text { important to care for the tracheostomy of patients and to manage sequelae } \\
\text { such as vocal cord injuries, glottic and subglottic stenosis. }\end{array}$ & 3a \\
\hline Schindler A & 2020 & $\begin{array}{l}\text { It is important within the evaluation of patients to use PPE, to maintain a } \\
\text { distance greater than } 1 \text { meter. If telemedicine can be used, it should always } \\
\text { be preferred in order to reduce exposure to the SARS-CoV- } 2 \text { virus. }\end{array}$ & 5 \\
\hline
\end{tabular}

* Centre of evidence-based medicine (CEBM). 


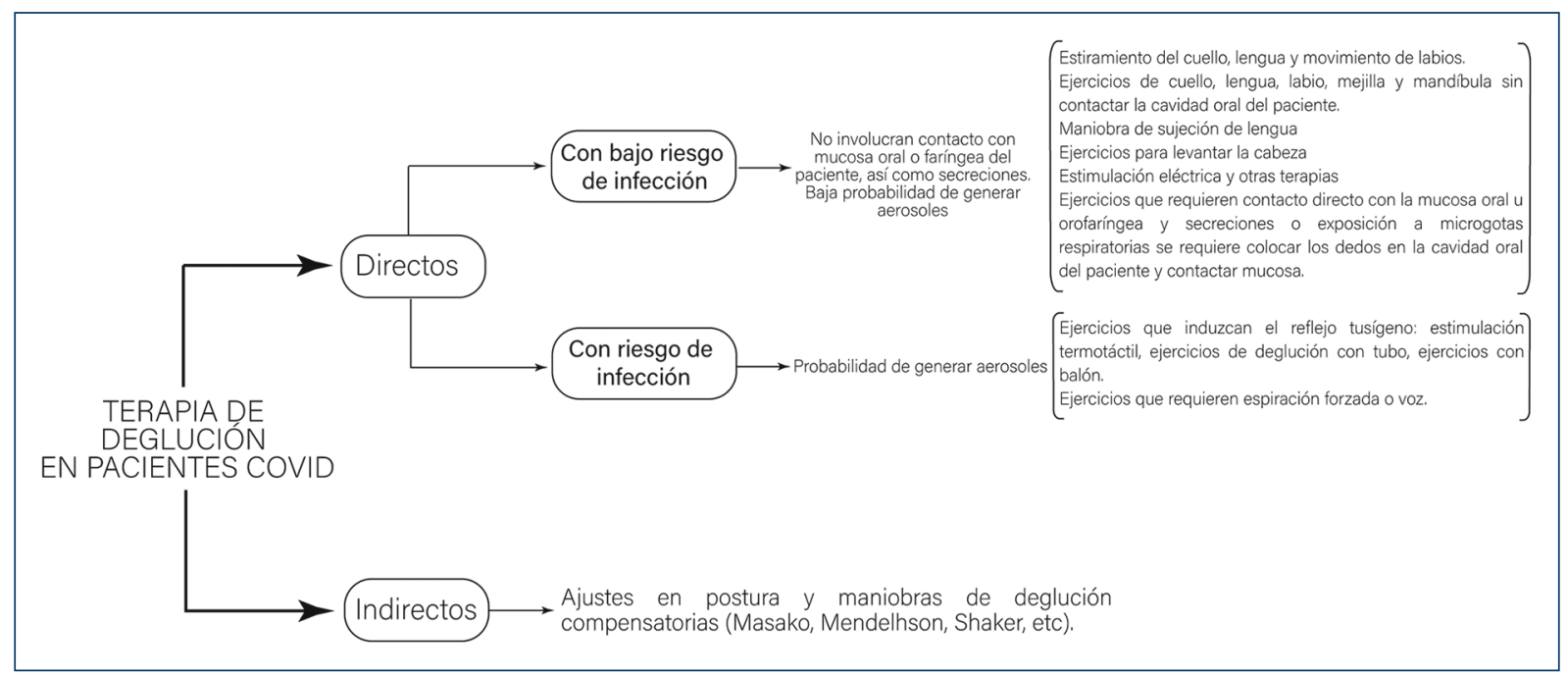

Figure 1. Direct and indirect interventions in swallowing therapy in COVID patients.

ventilator-compatible speech valves are recommended as long as the positive expiratory pressure (PEEP) is less than $8 \mathrm{cmH} 2 \mathrm{O}$. Similarly, it should be considered that the balloon of the cannula must be completely deflated before the valve is inserted to ensure that the expired air passes through the tracheostomy tube, always verifying that $\mathrm{CO} 2$ levels do not increase as a result ${ }^{10-16}$.

All of these steps must be taken to prevent dysphagia. It is considered that the use of speech valves and preventive and post-decannulation speech therapy reduces risks in patients with prolonged intubation, not only for dysphagia, but also for speech and voice in articulatory and sensory perception issues ${ }^{17-19}$.

\section{Diagnosis in COVID patients}

The gold standard for the diagnosis of dysphagia is the videofluoroscopic study of swallowing (VF), but the Fibroendoscopic Evaluation of Swallowing (FEES) has great sensitivity and specificity. Both procedures are aerosol generators (PGA), however, in a pandemic situation the study of choice is VF since the patient can take food by himself, reducing close contact ${ }^{5,20-23}$.

Stierli et al. suggest conducting a FEES when:

The clinical evaluation has failed and does not provide enough information to stage dysphagia or airway condition or it is incomplete information.

The patient has a previous history of aspiration pneumonia

A recent increase in symptoms such as fever, cough, and weight loss
Mismanagement of secretions or suspicion of silent aspiration ${ }^{22}$.

In the literature, it is recommended to use two consistencies for the FEES with two attempts of each, using the New Zealand Secretion Scale (NZSS), Yale Residue Scale (YRS) or Penetration Aspiration Scale (PAS) for staging ${ }^{10}$.

It is important to support the clinical evaluation with questionnaires for a comprehensive evaluation such as the Eating Assessment Tool (EAT-10), Sidney Swallow Questionnaire (SSQ), Royal Brisbane Hospital Outcome Measure for Swallowing (RBHOMS) or the Yale Swallow Protocol (YSP) $)^{23,24}$.

At all times, it is imperative to use full personal protective equipment (PPE) at the time of evaluations, which includes an N95 mask verifying that it seals properly, eye protection (mask or goggles), clean longsleeved gowns and gloves, preferably in a place with adequate ventilation. During the pandemic situation, it is advisable to perform out screening tests before carrying out these studies, among which are cervical auscultation of swallowing, viscosity volume test, among others, thus avoiding PGA unnecessarily 17,21,23,25,26.

\section{Rehabilitation of COVID patients}

Once the diagnosis has been made, it is necessary to start rehabilitation as soon as possible, even from the moment of hospitalization in patients who have 3 consecutive days of hemodynamic stability. This in order to prevent long-term effects and promote normal 
swallowing even before hospital discharge. During hospitalization after extubates and with tracheostomy, the posture should be emphasized when sitting, strengthening the muscles for swallowing, improving lung capacity and participation in different activities s, $, 2,4,27,28$.

For the rehabilitation of dysphagia, it is important to take into account that a multidisciplinary team is required to provide the best treatment to the patient. This team should include the speech therapist, speech pathologist, speech therapist, otolaryngologist, among others ${ }^{23,27}$.

Fritz MA et al. recommend that patients admitted for rehabilitation meet the following characteristics:

More than 7 days of diagnosis of COVID-19

At least 72 hours without fever or without fever even with medication

Stable respiratory rate and saturation

Clinical and radiological stability by $\mathrm{CT}$ or pulmonary ultrasound ${ }^{4}$.

There is a closeness between the patient and the health professional who provides the therapy, so there is a high risk of transmitting the virus. Both exercises, both indirect (no swallowing exercises) and direct (swallowing exercises) involve direct contact with the patient's oral mucosa, secretions, exposure to droplets and aerosols, according to Kimura, et al (Fig. 1) ${ }^{17}$.

Necessary precautions should be taken, such as the use of PPE during therapy, and even in cases where telemedicine can be used. In cases where there is a shortage of material, therapy must be suspended ${ }^{6,8,21,22}$.

There are different interventions for swallowing therapy. The risk of transmission of COVID-19 involved depends on the way in which they are carried out, dividing them into direct and indirect exercises (Fig. 1) 17, 21, 29-45.

\section{Conclusions}

In patients with dysphagia due to COVID-19 infection, it is important to take into account that most of the conventional evaluation and treatment procedures involve closeness to the patient, as well as the generation of aerosols. This is why it is necessary to decide what is the risk-benefit of using most of the instruments used for diagnosis and assess which exercises help to maintain social distancing.

Updates regarding recommendations should be consulted frequently, and as it is a new virus, investigations continue and new recommendations are constantly published; besides that with the passage of time. It is imperative to be able to carry out clinical studies with high levels of evidence that allow us to generate Clinical Practice Guidelines for the benefit of our patients.

\section{Acknowledgments}

In gratitude to the people who collaborated in the writing of this article.

\section{Funding}

No funding of any kind was required to make this article.

\section{Conflict of interests}

The authors do not declare having any conflict of interest.

\section{Ethical disclosures}

Protection of human and animal subjects. The authors declare that no experiments were performed on humans or animals for this study.

Confidentiality of data. The authors declare that they have followed the protocols of their work center on the publication of patient data.

Right to privacy and informed consent. The authors have obtained the written informed consent of the patients or subjects mentioned in the article. The corresponding author is in possession of this document.

\section{References}

1. Mohan R, Mohapatra B. Shedding Light on Dysphagia Associated With COVID-19: The What and Why. Am Acad Otolaryngol neck Surg. 2020;4(2):2-3.

2. Dawson C, Capewell R, Ellis S, Matthews S, Adamson S, Wood M, et al. Dysphagia presentation and management following COVID-19: an acute care tertiary centre experience. J Laryngol Otol. 2020;

3. Aguayo-Albasini JL, Flores-Pastor B, Soria-Aledo V. GRADE System: Classification of Quality of Evidence and Strength of Recommendation. Cirugía Española (English Ed. 2014;92(2):82-8.

4. Carda S, Invernizzi M, Bavikatte G, Bensmaïl D, Bianchi F, Deltombe T, et al. COVID-19 pandemic. What should Physical and Rehabilitation Medicine specialists do ? A clinician's perspective. Eur J Phys Rehabil Med. 2020;56(4):515-24.

5. Fritz MA, Howell RJ, Brodsky MB, Suiter DM, Dhar SI, Rameau A, et al. Moving Forward with Dysphagia Care : Implementing Strategies during the COVID - 19 Pandemic and Beyond. Dysphagia. 2020.

6. Lara Fernández R, Natalia Cabrera S, Diego Fernández O, Lorena Olcese. Disfagia en tiempos de COVID-19 Dysphagia in COVID-19 times. Rev Otorrinolaringol Cir Cabeza Cuello. 2020;385-94.

7. Sepulveda V, Waissbluth S, González C. Anosmia y enfermedad por Coronavirus 2019 (COVID-19): ¿ Qué debemos saber ? Rev Otorrinolaringol Cir Cabeza Cuello. 2020;2019:247-58.

8. Alfaro-Arias LI, Ballesteros-rodríguez LA, Posada-álvarez ME, Martínez-estrada A. Alteraciones en el olfato y el gusto asociadas con la infección por SARS-CoV2: una revisión. Acta Otorrinolaringol Cirugía Cabeza y Cuello. 2020;48(4):316-21.

9. García Pérez A, Sánchez Figueras Y, Hernández Navarro MI, Sánchez García AJ, Sánchez García F. Disfunciones quimiosensoriales del olfato y el gusto provocadas por el SARS-CoV-2. Rev Inf Científica. 2021;(2):1-15. 


\section{A. Gómez-Coello et al.: Rehabilitation in post-COVID dysphagia}

10. Vergara J, Lirani-Silva $C$, Brodsky MB, Miles A, Clavé P, Nascimento W, et al. Potential Influence of Olfactory, Gustatory, and Pharyngolaryngea Sensory Dysfunctions on Swallowing Physiology in COVID-19. Am Acad Otolaryngol neck Surg. 2020.

11. Álvarez $\mathrm{H}$, Villamor P. Revisión de la literatura Complications of tracheostomy in pediatric patients. Literature review. Rev Otorrinolaringol Ci Cabeza Cuello. 2018;78:318-25.

12. Che-morales JL, Díaz-landero $P$, Cortés-tellés $A$. Manejo integral del paciente con traqueostomía. Neumol Cir Torax. 2014;73(4):254-62.

13. Cheung NH, Napolitano LM. Tracheostomy: epidemiology, indications, timing, technique, and outcomes. Respir Care. 2014; 59: 895-919.

14. Dal'Astra AP, Quirino AV, Caixêta JA, Avelino MA. Tracheostomy in childhood: review of the literature on complications and mortality over the last three decades. Braz J Otorhinolaryngol 2017; 83: 207-14.

15. Gaudreau PA, Gree nlick H, Dong T, Lev y M, Hackett A, Preciado D, Zalz al G, Reill y BK. Preventing Complications of Pediatric Tracheostomy Through Standardized Wound Care and Parent Education. JAMA Otolaryngol Head Neck Surg 2016; 142: 966-71.

16. Funamura JL, Yuen S, Kawai K, Gergin O, Adil E, Rahbar R, Watters K Characterizing mortality in pediatric tracheostomy patients. Laryngoscope 2017; 127: 1701-6.

17. Kimura Y, Ueha R, Furukawa T, Oshima F. Society of swallowing and dysphagia of Japan : Position statement on dysphagia management during the COVID-19 outbreak. Auris Nasus Larynx [Internet]. 2020. Available from: https://doi.org/10.1016/j.anl.2020.07.009

18. Cabezas V, Rosales F. Relación entre los trastornos de la deglución y pacientes traqueostomizados: una revisión sistemática. Rev Logop. 2017.

19. Saavedra Mendoza AG, Akaki Caballero M. Puntos esenciales en el protocolo de decanulación traqueal. An Orl Mex. 2014;59:254-61.

20. Stierli S, Buss I, Redecker H, Baumberger M, Blättler E, Selb M, et al. Insights from an interprofessional post-COVID-19 rehabilitation unit: A speech and language therapy and respiratory medicine perspective. J Rehabil Med. 2020;

21. Brodsky MB. The Long-Term Effects of COVID-19 on Dysphagia Evaluation and Treatment. Arch Phys Med Rehabil. 2020;101(January).

22. Vergara J, Skoretz S, Brodsky MB, Miles A, Langmore SE, Wallace S et al. Assessment, Diagnosis, and Treatment of Dysphagia in Patients Infected With SARS-CoV-2: A Review of the Literature and International Guidelines. Am J Speech-Language Pathol. 2020;29(November):2242-53.

23. Paper O, Coutts KA, Africa S, Coutts K. Dysphagia services in the era of COVID-19: Are speech-language therapists essential ? Dysphagia and COVID-19: A brief overview. 2020;1-6.

24. Fernández-rosati J, Lera L, Fuentes-López E, Albala C. Validez y confiabilidad del cuestionario Eating Assessment Tool 10 (EAT-10) para detectar disfagia en adultos mayores chilenos. Rev Med Chile. 2018;1008-15

25. Castillo-Allendes A, Contreras-Ruston F, Cantor, Lady, Codino J, Guzman M, Manzano C, et al. Terapia Vocal No Contexto Da Pandemia Do Covid-19; Orienta ${ }_{3}$ coes para a pratica clinica. J Voice. 2020;(January).

26. Agostini F, Mangone M, Ruiu P, Paolucci T, Santilli V, Bernetti A. Rehabilitation settings during and after covid-19: an overview of recommendations. J Rehabil Med. 2021:53.

27. Mooney B, Lawrence C, Johnson EG, Ccc-slp MS, Ndt C, Slaboden A et al. How COVID-19 Patients Were Moved to Speak: A Rehabilitation Interdisciplinary Case Series. 2020;16(December 2019):56-63.
28. Pandian V, Brodsky MB, Brigham EP, Parker AM, Hillel AT, Levy JM, et al. COVID-19 survivorship: How otolaryngologist-head and neck surgeons can restore quality of life after critical illness. Am J Otolaryngol Neck Med Surg. 2020;(January).

29. Meister KD, Pandian V, Hillel AT, Walsh BK, Brodsky MB, Balakrishnan K, et al. Multidisciplinary Safety Recommendations After Tracheostomy During COVID-19 Pandemic: State of the Art Review.

30. Schindler A, Baijens LWJ, Clave P, Degen B, Duchac S, Dziewas R ESSD Commentary on Dysphagia Management During COVID Pandemia. Dysphagia [Internet]. 2020;(0123456789):17-20. Available from: https://doi.org/10.1007/s00455-020-10194-z

31. Perry A, Sh L, Cotton S, Kennedy C. Therapeutic exercises for affecting post-treatment swallowing in people treated for advanced-stage head and neck cancers (Review). 2016;(8).

32. Kato K, Ikeda R, Suzuki J, Hirano-kawamoto A, Kamakura Y, Fujiu-kurachi M, et al. Questionnaire survey on nurses and speech therapists regarding dysphagia rehabilitation in Japan. Auris Nasus Larynx [Internet]. 2020;(xxxx). Available from: https://doi.org/10.1016/j.anl.2020.08.004.

33. Guillen-sola A, Soler NB, Marco E, Pera-cegarra O, Foro P. Effects of prophylactic swallowing exercises on dysphagia and quality of life in patients with head and neck cancer receiving (chemo) radiotherapy : the Redyor study, a protocol for a randomized clinical trial. 2019;1-7.

34. Exarchakos G, Givissis P, Beris A. Cervical isometric exercises improve dysphagia and cervical spine malalignment following stroke. 2018;54(6):845-52.

35. Govender R, Smith $\mathrm{CH}$, Taylor SA, Barratt H, Gardner B. Swallowing interventions for the treatment of dysphagia after head and neck cancer : a systematic review of behavioural strategies used to promote patient adherence to swallowing exercises. BMC Cancer [Internet]. 2017;1-15. Available from: http://dx.doi.org/10.1186/s12885-016-2990-x

36. Langmore SE, Pisegna JM. Efficacy of exercises to rehabilitate dysphagia : A critique of the literature. Int J Speech Lang Pathol [Internet]. 2015;1-8. Available from: http://dx.doi.org/10.3109/17549507.2 015.1024171

37. Park J, An D, Oh D, Chang M. Effect of chin tuck against resistance exercise on patients with dysphagia following stroke : A randomized pilot study. 2018;42:191-7.

38. Medica EM, Article O. versus Shaker exercise on dysphagia and. 2017; (June):426-32.

39. Remedios L, Parra-egeda J, Vega-ram FA. Treatment of Dysphagia in Parkinson's Disease : A Systematic Review.:1-13.

40. Article R. A Systematic Review of Isometric Lingual Strength-Training Programs in Adults With and Without Dysphagia. 2017;1-16.

41. Langmore SE, Mcculloch TM, Krisciunas GP, Lazarus CL, Daele DJ Van, Pauloski BR, et al. Efficacy of electrical stimulation and exercise for dysphagia in patients with head and neck cancer : A randomized clinical trial. 2016;(April):1221-31.

42. At $M$, Dodrill $P$, Ec W. Interventions for oropharyngeal dysphagia in children with neurological impairment (Review). 2012;(10).

43. Choi J, Shim S, Yang J, Kim H, Lee D, Park J. Effects of Shaker exercise in stroke survivors with oropharyngeal dysphagia. 2017.

44. Trial RC. Effects of game-based chin tuck against resistance exercise vs head-lift exercise in patients with dysphagia after stroke: an assessor-blind, randomized controlled trial. 2019.

45. Vose A, Nonnenmacher J, Singer ML. Dysphagia Management in Acute and Sub-acute Stroke. 2014;197-206. 